
\title{
28 Research Suare \\ Episodes Of Violence Suffered By Migrants \\ Transiting Through Libya: A Cross Sectional Study
}

laura reques ( $\nabla$ requeslaura@hotmail.com )

Medecins du Monde France https://orcid.org/0000-0003-1589-8012

\section{E Aranda-Fernandez}

Medecins du Monde France

\section{Rolland}

Medecins du Monde France
A Grippon
Medecins du Monde France
C Reboul
Medecins du Monde France
N Godard
Medecins du Monde France
N Luhmann
Medecins du Monde France

Short report

Keywords: Migration, violence, Libya, healthcare access

Posted Date: January 7th, 2020

DOI: https://doi.org/10.21203/rs.2.20172/v1

License: (c) (i) This work is licensed under a Creative Commons Attribution 4.0 International License.

Read Full License 


\section{Abstract}

Introduction The Central Mediterranean Route (CMR), passing through Libya, is one of the most dangerous for migrants from Africa. Episodes of violence have been documented but have not been accurately quantified. The objective of the study was to estimate the prevalence of episodes of violence suffered in Libya by migrants consulting Médecins du Monde (MdM) programs in France.

Methodology Monocentric cross-sectional study. The inclusion criteria included all migrants over the age of 18 who had passed through Libya, who arrived in Europe from 2017 and consulted at the MdM health centre in Paris. The presence of psycho-traumatic events was considered as exclusion criteria. The study was implemented from February to May 2019. An ad-hoc questionnaire was created. The proportion, frequency and factors associated to physical, deprivation and sexual violence were estimated, as well as access to health care and need for psychosocial support.

Results 98 people were recruited and 72 were interviewed ( 17 refused to participate and 9 were excluded). $76.4 \%$ were men, the average age was 31.9 years, $76.4 \%$ had a low level of education, $66.7 \%$ came from Ivory Coast and $59.7 \%$ had left their country for security reasons. The median length of stay in Libya was 180 days. The overall proportion of persons having suffered violence was $96.4 \%$ for men and $88.2 \%$ for women. The prevalence of physical, deprivation and sexual violence was $94.2 \%, 81.7 \%$ and $18 . \%$ for men and $80.0 \%, 86.7 \%$ and $53.3 \%$ for women, respectively. No statistical differences by other variables were found. Access to health care in Libya was non-existent. $63.9 \%$ of participants were oriented for psychosocial support.

Conclusions The vast majority of migrants report having been victims of violence during their transit in Libya. Women are at particular risk of sexual violence. Mental health support for these populations is urgent.

\section{Background}

Several studies have shown that a high percentage of migrants reported a history of violence related to migration, including physical assault, torture and sexual violence (1-4). Among the migratory routes taken, the so-called "Central Mediterranean Route" (CMR) which crosses Libya is one of the most dangerous (2) .

Libya has been more frequently indexed by the media for its migration policy, and many reports of violence suffered by migrants have been collected. Most of these are hold by non-governmental organizations (5-7). Nevertheless, scientific evidence lacks robust quantitative data.

Moreover, real interest has been raised in the healthcare and reception centres concerning the subject of violence in Libya. Indeed, it was common during consultations by doctors, nurses and psychologists to objectivate psycho traumatic symptoms among patients having transited through Libya. Professionals have expressed willingness to participate in this study and to document reported violence. 
In this context, the objective of this study was to quantify the episodes of violence according to their typology and factors associated, as well as health care access and need of psychosocial support for migrants transiting Libya and visiting Médecins du Monde (MdM) programs.

\section{Methods}

The study was cross-sectional and monocentric. The target population were the beneficiaries of the Médecins du Monde healthcare centre in Paris. Inclusion criteria included age over 18 years old, foreign nationality, having transited Libya and having arrived in Europe from 2017. Participants were excluded if they presented a risk of psychiatric decompensation. Recruitment was systematic until achieving the sample size.

Estimated sample size according to an estimated proportion of $95 \%$ migrants suffering violence, a margin of error of $5 \%$ (estimated proportion $\pm 5 \%=$ confidence interval), and an confidence interval $(\mathrm{Cl})$ of $95 \%$ was 72 individuals.

The data collection tool was a questionnaire ah-hoc in online format (Kobo Collect application). Data were automatically integrated into a secure database. A pre-test period was conducted in order to test the survey feasibility.

The study differentiated between physical, sexual and deprivation violence. Physical violence distinguished including firearms (injury, aggression, shot) and not including firearms (physical injury, beatings, threat), sexual violence included harassment and rape, deprivation violence included detention, food deprivation, confiscation of property, racketeering, separation of spouses, family members or accompanying persons. Healthcare access was also addressed.

The descriptive analysis of sociodemographic characteristics, episodes of violence and associated factors used mean \pm standard deviation as well as median and interquartile range for continuous data. Percentages with a 95\% confidence interval were used for discontinuous data. T-Student tests were used for continuous variables and the Chi2 tests for categorical variables. Stata v. 15 software was used for statistical analysis.

\section{Main Findings}

98 people were recruited and 72 were interviewed from February to Mai 2019 (17 refused to participate and 9 were excluded because of psychological decompensation).

Table 1 describes the population and the episodes of different types of violence. 72 people were interviewed (55 men and 17 women). Mean age was 31.9 years ( $32.5 \mathrm{y} / \mathrm{o}$ for men and $30.2 \mathrm{y} / \mathrm{o}$ for women), $76.4 \%$ had primary studies, $66.6 \%$ came from Ivory Coast (followed by Mali $23.6 \%$ ). $59.7 \%$ of the participants left their country due to security reasons (59.7\%) followed by economic reasons $(22.2 \%)$. $69.4 \%$ of participants travelled alone and $29.4 \%$ of women were pregnant at some stage of the travel. 
Mean stay in Libya was 180 days and only $2.8 \%$ had access to healthcare in this country. At the time of the interview $63.9 \%$ of the participants were in need of a psychological treatment. Statistically significant differences by sex were found in the level of education $(p=0.03)$, the type of travel $(p=0.01)$, and healthcare access $(p=0.05)$.

According to the episodes of direct and witnessed violence, results show that $94.4 \%$ of the participants have suffered some type of violence ( $93.6 \%$ of men and $88.2 \%$ of women). $91.1 \%$ of participants suffered from physical violence ( $80.0 \%$ of women and $94.3 \%$ of men). Men were more likely to suffer from gun violence $(82.7 \%)$ than women $(53.5 \%)(p=0.02)$ as well as suffering violence without guns $(p=0.05)$.

$89.5 \%$ of participants experienced violence with deprivation ( $81.7 \%$ of men and $86.7 \%$ of women) and $26.5 \%$ suffered sexual violence ( $18.9 \%$ of men and $53.3 \%$ of women). There were statistically significant differences between sexes for both variables $(p<0.05)$. $49.1 \%$ of men and $22.2 \%$ of women experienced forced labour. This difference by sex was also statistically significant $(p=0.03)$. In addition, $17.6 \%$ of women had unsafe abortions during the journey.

$100 \%$ of participants witnessed some kind of violence, with $93.1 \%$ witnessing physical violence, $94.4 \%$ deprivation violence, $79.2 \%$ sexual violence and $88.2 \%$ other types of violence. No statistically significant differences by sex were found.

Table 2 describes episodes of physical, deprivation and sexual violence by sociodemographic characteristics and other secondary variables, showing no statistically significant differences by any of them.

\section{Discussion}

Human rights' violations suffered by migrants in Libya have been documented for years by international organizations and agencies, think tanks or journalists $(5,8-10)$. The average stay of more than 6 months shows that the vast majority of people suffer from long imprisonment and confinement. As it has been stated in this study, violence is systematic and of a huge magnitude. In most of the cases (more than $80 \%$ ), episodes of physical violence were suffered every day or almost every day and privation episodes were very long (sometimes for the whole journey) (data no shown). In addition, perpetrators are very difficult to identify (more than a half of the people interviewed could not identify their aggressors, and they simply called them "the Arabs") (data no shown).

Physical violence occurs mainly in places of confinement and is closely linked to the exploitation of migrants, forced labour and extortion. Many NGOs have denounced the inhuman conditions of these places of confinement $(5,11,12)$. Firearms are very common and often used for threat, but also including mass murders and shooting. A large number of reports mention that extortion is a common practice. However, NGOs note that migrants are often abducted by smugglers when they arrive in the country. They 
can be released if they pay, themselves or their families. They could also be sold to another smuggling group $(5,11)$.

Women are particularly vulnerable to sexual violence. This result has also been documented by other studies pointing that sexual violence is a common practice during the detentions or before being released for the trip (4,13-15). In addition, $35 \%$ of the victims of sexual violence of the study stated that episodes were very common (daily or almost daily and by multiple perpetrators, -data no shown-). In addition, the results of the study show that men are also exposed to sexual violence. Nevertheless, data around sexual violence may be underestimated, especially for men, as the nature of the violence, which affects their privacy, sexuality and gender identity, makes it more difficult to testify or speak about.

As it has been stated in our results, access to health care in Libya is almost non-existent. Access to health care is generally provided by very few international organizations. Nevertheless, in our study no one had ever been treated by a doctor or had received medication during their stay. The health system in Libya is collapsed and it is facing serious problems due to infrastructure damage, lack of medicines, medical equipment and personnel (10). Access to medical care has become a problem for all people living in Libya, especially migrants, whether detained or not (16).

Most people asked for psychological support after the questionnaire, reflecting a real urgency. Publications documenting migrants' mental health disorders as a consequence of their journey are numerous. The main factors mentioned are traumatic events before migration, forced, unplanned, poorly planned or illegal migration, low level of acculturation, isolation or separation of the family in the host country, lack of support, perceived discrimination and length of residence of the host migrants (17-19).

\section{Limits}

This study has a number of limits. Firstly, the recruitment was hold in the Paris healthcare centre, which restricts the profile of participants and may affect the external validity of the study. In addition, the refusal and exclusion linked to risk of psychological decompensation could have avoided the most vulnerable patients from participating in the study, probably due to the difficulty of evoking traumatic experiences. Moreover, it is very possible that sexual violence was underestimated among men, as it was normally evoked as witnessed. Finally, the low proportion of women included could also limit the statistical power for this group.

\section{Conclusions}

Violence in Libya is structural and systematic. Episodes of physical violence and deprivation are very common for men and women. The latter are also very exposed to sexual violence. The lack of access to care in Libya is almost total. It is urgent to develop a strategy to provide psychosocial and medical support to migrants suffering from violence.

\section{Abbreviations}


Cl: Confidence Intervalle

CMR: Central Mediterranean Route

INSERM : Institut national de la santé et de la recherche médicale

IQR : Inter Quartile Range

IRB : Institutional Review Board

MdM: Médecins du Monde

NGO: Non Governmental Organization

SD : Standard Deviation

UN: United Nations

UNSMIL: United Nations Mission in Libya

\section{Declarations}

\section{Ethics approval and consent to participate}

This research project was approved by the INSERM Institutional Review Board (IRB). The study was conducted in compliance with the ethical principles of the Helsinki Declaration. All participants were informed of the study's objectives and design, and their participation was voluntary after providing verbal informed consent.

\section{Consent for publication}

Not applicable.

\section{Availability of data and materials}

The datasets used and/or analysed during the current study are available from the corresponding author on reasonable request.

\section{Competing interests}

The authors declare that they have no competing interests 


\section{Funding}

Médecins du Monde

\section{Authors' contributions}

NL, CR, NG and AG have participated on the study conception and design. LR, CR, EAF have implemented and coordinated the data collection and analysis. LR, EAF wrote the first article draft. All authors commented on the draft and provided substantial inputs. All authors read and approved the final manuscript.

\section{Acknowledgements}

We are grateful to all the participants of this study for their valuable testimonies. We are also grateful to all volunteers and employees who collaborated in the different stages of the study, and all the collaborators in MdM headquarters (France operations, Health and Advocacy Direction).

\section{References}

1. Altai Consulting. Mixed migration trends in Libya: Changing dynamics and protection challenges, Altai Consulting in partnership with IMPACT Initiatives, for the UNHCR in Libya, 2017 [Internet]. Disponible sur: http://www.altaiconsulting.com/wp-content/uploads/2017/08/2017_MixedMigration-Trends-in-Libya-Final-Report-Web.pdf

2. UNHCR. Mediterranean Situation [Internet]. Disponible sur: https://data2.unhcr.org/en/situations/mediterranean/location/5205

3. IOM. Four decades of cross Mediterranean. four_decades_of_cross_mediterranean [Internet]. 2019. Disponible sur: https://publications.iom.int/system/files/pdf/four_decades_of_cross_mediterranean.pdf

4. DRC. Going West. Migration trends from Libya to Europe [Internet]. Disponible sur: https://drc.ngo/media/2846076/going_west_migration_trends_libya_europe_final.pdf

5. Amnesty International. EU risks fuelling horrific abuse of refugees and migrants in Libya [Internet]. 2016. Disponible sur: https://www.amnesty.org/en/latest/news/2016/06/eu-risks-fuelling-horrificabuse-of-refugees-and-migrants-in-libya/

6. Dollet S. Violence perpetrated in Libya against exiled persons \& consequences on health observed after arrival in Europe A focus on the impact of EU as well as Italian \& French policies. Médecins du Monde; 2018. 
7. DMT. Libya - Migrant Report Information Package 18 (March 2018) [Internet]. 2018. Disponible sur: https://www.globaldtm.info/dtm-libya-migrant-report-information-package-18-march-2018/

8. Rights Watch. EU/NATO: Europe's Plan Endangers Foreigners in Libya [Internet]. Disponible sur: EU/NATO: Europe's Plan Endangers Foreigners in Libya

9. Migreurop. Libya. The hounding of migrants must stop [Internet]. Disponible sur: http://www.migreurop.org/IMG/pdf/109697240-Report-Migrants-Libya.pdf

10. Oun AM, Hadida EM, Stewart C. Assessment of the Knowledge of Blast Injuries Management among Physicians Working in Tripoli Hospitals (Libya). Prehospital Disaster Med. juin 2017;32(3):311-6.

11. MSF. Arbitrary detention of refugees, asylum-seekers and migrants must stop [Internet]. 2017. Disponible sur: https://www.msf.org/libya-arbitrary-detention-refugees-asylum-seekers-and-migrantsmust-stop

12. MEDU. Rapporto sulle condizioni di grave violazione dei diritti umani dei migranti in Libia (20142017) [Internet]. 2018. Disponible sur: http://www.mediciperidirittiumani.org/wpcontent/uploads/2017/12/Rapporto-per-Tribunale-Permanente-dei-Popoli.pdf

13. Amnesty International. Refugees and migrants fleeing sexual abuse and explotaition in Libya [Internet]. 2016. Disponible sur: https://www.amnestyusa.org/press-releases/refugees-and-migrantsfleeing-sexual-violence-abuse-and-exploitation-in-libya/

14. Freedman J. Sexual and gender-based violence against refugee women: a hidden aspect of the refugee « crisis ». Reprod Health Matters. mai 2016;24(47):18-26.

15. Vu A, Adam A, Wirtz A, Pham K, Rubenstein L, Glass N, et al. The Prevalence of Sexual Violence among Female Refugees in Complex Humanitarian Emergencies: a Systematic Review and Metaanalysis. PLoS Curr. 18 mars 2014;6.

16. Zarocostas J. Libya: war and migration strain a broken health system. Lancet Lond Engl. 03 2018;391(10123):824-5.

17. Crepet A, Rita F, Reid A, Van den Boogaard W, Deiana P, Quaranta G, et al. Mental health and trauma in asylum seekers landing in Sicily in 2015: a descriptive study of neglected invisible wounds. Confl Health. 2017;11:1.

18. Abbott A. The mental-health crisis among migrants. Nature. 13 2016;538(7624):158-60.

19. Bianucci R, Charlier P, Perciaccante A, Lippi D, Appenzeller O. The « Ulysses syndrome »: An eponym identifies a psychosomatic disorder in modern migrants. Eur $\mathrm{J}$ Intern Med. juin 2017;41:30-2.

\section{Tables}

Table 1. Sociodemographic characteristics and episodes of violence in Libya by type and sex: 


\section{SOCIODEMOGRAPHIC CHARACTERISTIQUES}

Age in years (Mean, SD)

Level of Education (\%)

Primary

Secondary

Higher

Country of Origin (\%)

Ivory Coast
Mali

\section{Eritrea}

Republic of Cameroon

Reasons for leaving country of origin (\%)

Security

\section{Economic}

Studies

Type of travel (\%)

\begin{tabular}{|c|c|c|c|c|c|c|c|}
\hline \multicolumn{8}{|l|}{ Type of travel (\%) } \\
\hline Alone & 69,4 & $(50 / 72)$ & 41,2 & $(7 / 17)$ & 78,2 & $(43 / 55)$ & \multirow[t]{3}{*}{$0,01^{*}$} \\
\hline With family & 19,4 & $(14 / 72)$ & 35,3 & $(6 / 17)$ & 14,5 & $(4 / 55)$ & \\
\hline Other & 11,1 & $(8 / 72)$ & 23,5 & $(4 / 17)$ & 7,3 & $(8 / 55)$ & \\
\hline Pregnancy during travel (\%) & - & - & 29,4 & $(5 / 17)$ & - & - & - \\
\hline \multirow[t]{2}{*}{ Boarding by threat (\%) } & 58,1 & $(42 / 72)$ & 47,1 & $(8 / 17)$ & 61,8 & $(34 / 55)$ & 0,68 \\
\hline & & (IQR 120- & & & & & $0,02^{*}$ \\
\hline Length of stay in Libya (median, IQR) & 180 & 365) & 120,0 & (IQR 60-180) & 200 & (IQR 120-365) & \\
\hline Healthcare access in Libya (\%) & 2,8 & $(2 / 72)$ & 0 & $(0 / 17)$ & 3,6 & $(2 / 55)$ & $0,05^{*}$ \\
\hline Need of psychological support after the survey (\%) & 63,9 & $(46 / 72)$ & 70,8 & $(12 / 17)$ & 61,8 & $(34 / 55)$ & 0,35 \\
\hline
\end{tabular}

EPISODES OF DIRECT VIOLENCE (\%, CI 95\%)

\begin{tabular}{|c|c|c|c|c|c|c|}
\hline 31,9 & $(\mathrm{SD} 7,4)$ & 30,2 & $(\mathrm{SD} 7,8)$ & 32,5 & $(\mathrm{SD} 7,3)$ & 0,27 \\
\hline 76,4 & $(55 / 72)$ & 100,0 & $(17 / 17)$ & 69,1 & $(38 / 55)$ & $0,03^{*}$ \\
\hline 18,1 & $(13 / 72)$ & 0,0 & $(0 / 17)$ & 23,6 & $(13 / 55)$ & \\
\hline 5,5 & $(4 / 72)$ & 0,0 & $(0 / 17)$ & 7,3 & $(4 / 55)$ & \\
\hline
\end{tabular}

\begin{tabular}{rrrrrrr}
66,6 & $(48 / 72)$ & 82,4 & $(14 / 17)$ & 61,8 & $(34 / 55)$ & 0,51 \\
23,6 & $(17 / 72)$ & 17,6 & $(3 / 17)$ & 25,5 & $(14 / 55)$ & \\
1,4 & $(1 / 72)$ & 0,0 & $(0 / 17)$ & 1,8 & $(1 / 55)$ \\
\hline 5,6 & $(4 / 72)$ & 0,0 & $(0 / 17)$ & 7,3 & $(4 / 55)$
\end{tabular}

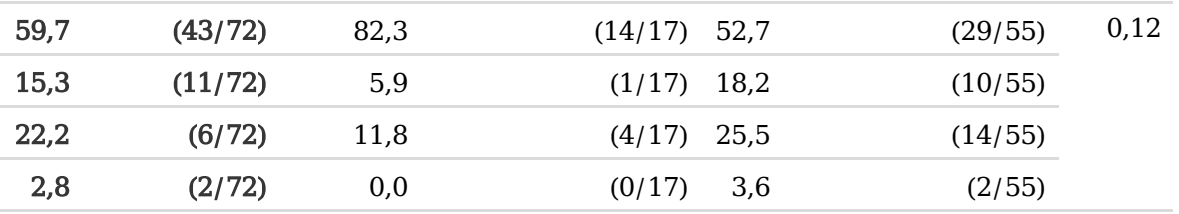

\begin{tabular}{rrrrrrr} 
& & & & & & \\
$\mathbf{6 9 , 4}$ & $(50 / 72)$ & 41,2 & $(7 / 17)$ & 78,2 & $(43 / 55)$ & $0,01 *$ \\
19,4 & $(14 / 72)$ & 35,3 & $(6 / 17)$ & 14,5 & $(4 / 55)$ & \\
11,1 & $(8 / 72)$ & 23,5 & $(4 / 17)$ & 7,3 & $(8 / 55)$ & \\
\hline- & - & 29,4 & $(5 / 17)$ & - & & - \\
\hline 58,1 & $(42 / 72)$ & 47,1 & $(8 / 17)$ & 61,8 & $(34 / 55)$ & 0,68 \\
\hline & $($ IQR $120-$ & & & & & $0,02 *$ \\
180 & $365)$ & 120,0 & $($ IQR $60-180)$ & 200 & $($ IQR $120-365)$ & \\
\hline 2,8 & $(2 / 72)$ & 0 & $(0 / 17)$ & 3,6 & $(2 / 55)$ & $0,05 *$ \\
\hline 63,9 & $(46 / 72)$ & 70,8 & $(12 / 17)$ & 61,8 & $(34 / 55)$ & 0,35 \\
\hline
\end{tabular}

\begin{tabular}{|c|c|c|c|c|c|c|c|}
\hline \multirow[b]{2}{*}{ Global Violence } & \multirow[b]{2}{*}{94,4} & \multirow[b]{2}{*}{$(89,0-99,9)$} & \multirow[b]{2}{*}{88,2} & \multirow[b]{2}{*}{$(71,3-100)$} & \multicolumn{3}{|c|}{$(91,3-$} \\
\hline & & & & & 96,3 & 100) & 0,21 \\
\hline & & & & & & $(87,9-$ & \\
\hline \multirow[t]{2}{*}{ Physical violence } & 91,1 & $(84,3-98,1)$ & 80,0 & $(57,1-100)$ & 94,3 & 100) & $0,05^{*}$ \\
\hline & & & & $(24,7-$ & & $(72,1-$ & \\
\hline \multirow[t]{2}{*}{ With guns } & 76,1 & $(65,6-86,6)$ & 53,5 & $81,9)$ & 82,7 & $93,3)$ & $0,02^{*}$ \\
\hline & & & & $(48,0-$ & & $(87,9-$ & \\
\hline \multirow[t]{2}{*}{ Without guns } & 89,5 & $(82,1-97,1)$ & 73,3 & $98,7)$ & 94,3 & 100) & $0,02^{*}$ \\
\hline & & & & & & $(85,6-$ & \\
\hline \multirow[t]{2}{*}{ Violence with deprivation } & 89,5 & $(82,1-97,1)$ & 86,7 & $(67,7-100)$ & 91,7 & 100) & 0,10 \\
\hline & & & & & & $(78,3-$ & \\
\hline \multirow[t]{2}{*}{ Detention without food } & 88,2 & $(79,3-98,1)$ & 86,7 & $(67,7-100)$ & 88,7 & $99,0)$ & 0,85 \\
\hline & & & & $(18,1-$ & & $(47,7-$ & \\
\hline \multirow[t]{2}{*}{ Detention with racket } & 58,8 & $(46,1-71,5)$ & 46,7 & $75,2)$ & 62,3 & $76,8)$ & 0,31 \\
\hline & & & & $(31,9-$ & & $(43,8-$ & \\
\hline \multirow[t]{2}{*}{ Detention with ransom } & 58,8 & $(46,1-71,5)$ & 60,1 & $88,0)$ & 58,5 & $73,2)$ & 0,92 \\
\hline & & & & $(18,1-$ & & $(19,7-$ & \\
\hline Family separation & 37,6 & $(24,2-49,2)$ & 46,7 & $75,2)$ & 34,0 & $48,2)$ & 0,40 \\
\hline Sexual violence & 26,5 & $(15,7-37,2)$ & 53,3 & $(24,7-$ & 18,9 & $(7,9-24,8)$ & $0,01 *$ \\
\hline
\end{tabular}


Other types of violence

$(17,5-$

\begin{tabular}{|c|c|c|c|c|c|c|c|}
\hline Forced labour & 33,3 & $(19,9-47,5)$ & 22,2 & $(9,8-35,6)$ & 49,1 & $82,1)$ & $0,03^{*}$ \\
\hline Insecure abortion & - & - & 17,6 & $(5,3-29,9)$ & - & - & _ \\
\hline \multirow{2}{*}{\multicolumn{8}{|c|}{$\begin{array}{l}\text { EPISODES OF WITNESSED VIOLENCE }(\%, \mathrm{CI} \\
95 \%)\end{array}$}} \\
\hline & & & & & & & \\
\hline \multirow[t]{2}{*}{ Global Violence } & 100,0 & $(100-100)$ & 100,0 & $(100-100)$ & 100,0 & $(100-100)$ & _ \\
\hline & & & & & & $(87,9-$ & \\
\hline \multirow[t]{2}{*}{ Physical violence } & 93,1 & $(85,9-100)$ & 88,2 & $(71,1-100)$ & 94,3 & 100) & 0,46 \\
\hline & & & & & & $(79,1-$ & \\
\hline \multirow[t]{2}{*}{ With guns } & 87,5 & $(78,7-93,2)$ & 82,4 & $(62,1-100)$ & 89,1 & $99,0)$ & 0,52 \\
\hline & & & & & & $(83,9-$ & \\
\hline \multirow[t]{2}{*}{ Without guns } & 93,1 & $(85,9-100)$ & 88,2 & $(71,1-100)$ & 92,7 & 100) & 0,87 \\
\hline & & & & & & $(91,3-$ & \\
\hline \multirow[t]{2}{*}{ Violence with deprivation } & 94,4 & $(89,0-99,9)$ & 88,2 & $(71,3-100)$ & 96,3 & 100) & 0,21 \\
\hline & & & & & & $(76,8-$ & \\
\hline \multirow[t]{2}{*}{ Detention without food } & 87,5 & $(78,3-96,5)$ & 88,2 & $(71,2-100)$ & 87,3 & $97,7)$ & 0,93 \\
\hline & & & & $(54,0-$ & & $(63,7-$ & \\
\hline \multirow[t]{2}{*}{ Detention with racket } & 76,4 & $(65,6-87,1)$ & 76,4 & $99,0)$ & 76,4 & $89,1)$ & 0,99 \\
\hline & & & & $(46,4-$ & & $(70,1-$ & \\
\hline \multirow[t]{2}{*}{ Detention with ransom } & 79,2 & $(68,8-89,6)$ & 70,6 & $94,7)$ & 81,8 & $93,6)$ & 0,37 \\
\hline & & & & $(26,5-$ & & $(49,5-$ & \\
\hline \multirow[t]{2}{*}{ Family separation } & 61,1 & $(48,9-73,3)$ & 52,9 & $79,4)$ & 63,6 & $77,6)$ & 0,46 \\
\hline & & & & & & $(65,8-$ & \\
\hline Sexual violence & 79,2 & $(68,8-89,6)$ & 82,4 & $(62,1-100)$ & 78,2 & $90,6)$ & 0,74 \\
\hline \multicolumn{8}{|l|}{ Other types of violence } \\
\hline \multirow{2}{*}{ Forced labour } & & & & & & $(78,3-$ & \\
\hline & 88,2 & $(79,3-98,1)$ & 86,7 & $(67,7-100)$ & 88,7 & $99,0)$ & 0,85 \\
\hline
\end{tabular}

*p values correspond to tow sample T-tests for continuous variables and to Chi-2 tests for categorical values. Values with * are statistically significant $(\mathrm{p}<0.05)$. SD: Standard deviation. IQR: Interquartile range.

Table 2. Episodes of physical, deprivation and sexual violence by secondary variables: 
Oui $\quad p$

Sex (\%)

\begin{tabular}{|c|c|c|c|c|c|c|c|c|c|c|c|c|}
\hline Male & 3,4 & 96,4 & 0,20 & 5,7 & 94 & 0,08 & 15,1 & 84,9 & 0,87 & 81,1 & 18,9 & $0,01 *$ \\
\hline Female & 11,6 & 88,2 & & 20 & 80 & & 13,3 & 86,7 & & 46,7 & 53,3 & \\
\hline \multirow{4}{*}{ Age in years (Mean, SD) } & & & 0,53 & & & & & & 0,61 & & & 0,71 \\
\hline & 30 & 32 & & 31 & 31,8 & 0,75 & 32 & 30,5 & & 30,7 & 34,4 & \\
\hline & ET & & & ET & & & ET & & & ET & & \\
\hline & $(5,0)$ & ET $(7,6)$ & & $(7,0)$ & ET $(8,6)$ & & $(6,7)$ & $\operatorname{ET}(7,9)$ & & $(6,1)$ & ET $(8,6)$ & \\
\hline
\end{tabular}

Level of Education (\%)

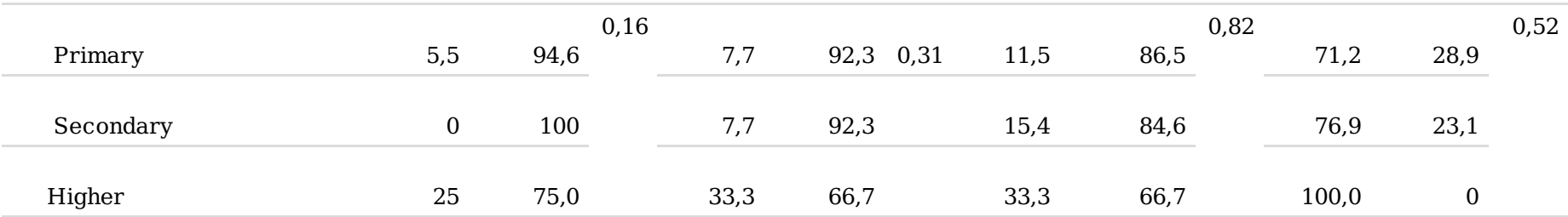

\section{Country of Origin (\%)}

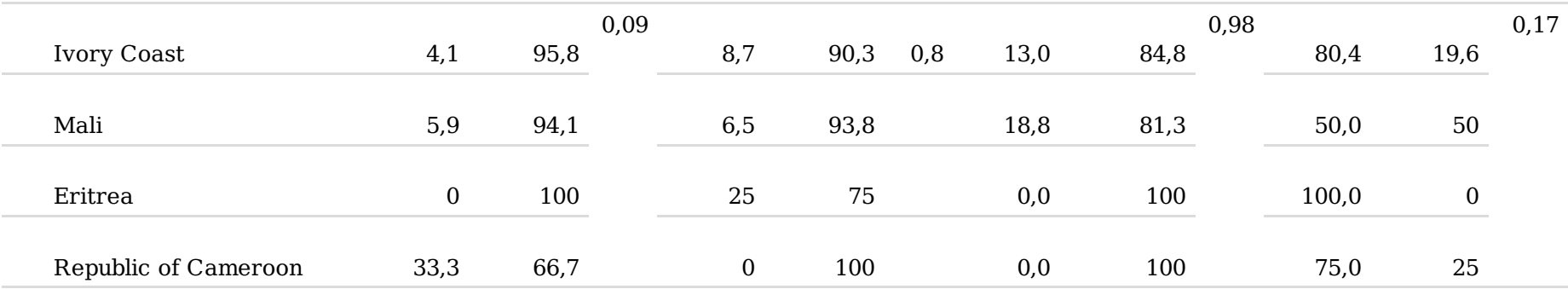

Type of travel (\%)

\begin{tabular}{|c|c|c|c|c|c|c|c|c|c|c|c|c|}
\hline & & & 0,45 & & & & & & & & & 0,55 \\
\hline Alone & 6 & 94 & & 6,4 & 93,6 & 0,57 & 14,9 & 83 & 0,79 & 74,5 & 25,5 & \\
\hline With family & 0 & 100 & & 14,3 & 85,7 & & 14,3 & 85,7 & & 64,5 & 35,7 & \\
\hline Other & 12,5 & 87,5 & & 14,3 & 85,7 & & 0,0 & 100 & & 85,7 & 14,3 & \\
\hline Length of stay in Libya & & & 0,79 & & & 0,81 & & & 0,83 & & & 0,86 \\
\hline \multirow[t]{3}{*}{ (median, IQR) } & 118,3 & 259,5 & & 122,5 & 270,3 & & 104,3 & 277,4 & & 109,3 & 268,5 & \\
\hline & ET & ET & & ET & ET & & ET & ET & & ET & ET & \\
\hline & $(70,1)$ & $(116,2)$ & & $(72,1)$ & $(126,6)$ & & $(76,1)$ & $(135,9,2)$ & & $(65,1)$ & $(126,2)$ & \\
\hline
\end{tabular}

*Les valeurs p se rapportent au test $\mathrm{T}$ à deux échantillons pour les variables continues et au test chi-carré pour les variables categoriques. 